\title{
Boundary Cap Neural Crest Stem Cells Promote Survival of Mutant SOD1 Motor Neurons
}

\author{
Tanya Aggarwal $^{1}$ - Jan Hoeber ${ }^{1}$ - Patrik Ivert ${ }^{1}$ - Svitlana Vasylovska ${ }^{1}$. \\ Elena N Kozlova ${ }^{1}$
}

Published online: 9 January 2017

(C) The Author(s) 2017. This article is published with open access at Springerlink.com

\begin{abstract}
ALS is a devastating disease resulting in degeneration of motor neurons (MNs) in the brain and spinal cord. The survival of MNs strongly depends on surrounding glial cells and neurotrophic support from muscles. We previously demonstrated that boundary cap neural crest stem cells (bNCSCs) can give rise to neurons and glial cells in vitro and in vivo and have multiple beneficial effects on co-cultured and coimplanted cells, including neural cells. In this paper, we investigate if bNCSCs may improve survival of MNs harboring a mutant form of human SOD1 (SOD $1^{\mathrm{G} 93 \mathrm{~A}}$ ) in vitro under normal conditions and oxidative stress and in vivo after implantation to the spinal cord. We found that survival of SOD $1^{\mathrm{G} 93 \mathrm{~A}}$ MNs in vitro was increased in the presence of bNCSCs under normal conditions as well as under oxidative stress. In addition, when $\mathrm{SOD} 1^{\mathrm{G} 93 \mathrm{~A}} \mathrm{MN}$ precursors were implanted to the spinal cord of adult mice, their survival was increased when they were co-implanted with bNCSCs. These findings show that bNCSCs support survival of SOD $1^{\text {G93A }}$ MNs in normal conditions and under oxidative stress in vitro and improve their survival in vivo, suggesting that bNCSCs have a potential for the development of novel stem cell-based therapeutic approaches in ALS models.
\end{abstract}

Keywords Amyotrophic lateral sclerosis .

Neurodegeneration $\cdot$ Neuroglia $\cdot$ Oxidative stress .

Transplantation

Tanya Aggarwal and Jan Hoeber contributed equally to this work.

Elena N Kozlova

elena.kozlova@neuro.uu.se

1 Department of Neuroscience, Uppsala University Biomedical Center, Box 593, 75124 Uppsala, Sweden

\section{Introduction}

Amyotrophic lateral sclerosis (ALS) is a progressive, neurodegenerative disorder affecting primarily upper and lower motor neurons (MNs), and usually leading to the death of the patient, most commonly due to respiratory failure. The glutamate signaling antagonist Riluzole has a measurable positive effect on disease progression and is relatively free of side effects. Riluzole acts by attenuating excitotoxic impact on endangered MNs, and is currently the only available approved ALS treatment, but offers not more than a few months extended life expectancy [1]. Riluzole exerts a wide range of neural effects which can influence neuronal activity and survival, although the mechanism of action still remains controversial [2]. About $10 \%$ of ALS cases are familial and several genetic mutations linked to this group of patients have been identified. Mutations in superoxide dismutase (SOD) 1 are found in about $20 \%$ of familial cases and in a few percent of sporadic ALS cases [3]. SOD1 is an enzyme that helps in the catalysis of dismutation of superoxide to molecular oxygen and hydrogen peroxide [3]. The association between mutant SOD1 and ALS onset, and the subsequent generation of transgenic animals harboring human mutant and non-mutant forms of SOD1, have played a pivotal role and remains a cornerstone in research on the pathogenesis of ALS and in the search for novel therapeutic treatment of this disease [3]. To date, more than 150 SOD1 mutations have been identified and SOD1 ${ }^{\mathrm{G} 93 \mathrm{~A}}$ is the most widely studied model for ALS pathogenesis [3].

Mutant SOD1 affects not only intrinsic properties of MNs, but also results in a neurotoxic astroglial phenotype, inducing degeneration of wild type MNs in vitro [4-7] and in vivo after transplantation into the spinal cord of rats [8]. Furthermore, astrocytes from patients with sporadic as well as familial ALS exert a toxic effect on primary MNs in vitro $[9,10]$. Conversely, deletion of mutant SOD1 in astrocytes of transgenic mice 
significantly delays disease progression [11]. Wild type astrocytes release factors that promote survival of co-cultured mutant SOD1 MNs [12]. Implantation of stem/progenitor cellderived astrocytes into the spinal cord or ventricular system of transgenic mice with mutant SOD1 promotes MN survival and delays disease progression [13, 14].

Boundary cap neural crest stem cells (bNCSCs) is a transient neural crest-derived group of cells that are located at the dorsal root entry zone (DREZ) [15]. These cells self-renew and show multipotency in culture and are able to differentiate into sensory neurons and Schwann cells in vitro and in vivo [15], as well as into astrocytes in vitro and after transplantation into the immature mouse brain [16]. We have previously shown remarkable, beneficial effects of bNCSCs on co-cultured $[17,18]$ and coimplanted pancreatic beta-cells [19], as well as excitotoxically challenged spinal cord neurons in vitro (unpublished observation). Interestingly, another type of NCSCs, the hair follicle stem cells, did not have corresponding positive effects on cocultured cells [20].

These findings prompted us to test if bNCSCs have a beneficial effect on co-cultured and co-implanted SOD $1{ }^{\mathrm{G} 93 \mathrm{~A}} \mathrm{MNs}$, generated from SOD $1{ }^{\mathrm{G} 93 \mathrm{~A}}$ mouse embryonic stem cells (mESCs). These cell lines express green fluorescent protein (GFP) under the control of the promoter for the MN specific transcription factor HB9 (HB9::GFP cells), allowing their identification after directed differentiation to MN progenitors [21]. Furthermore, the survival of MN from the same SOD ${ }^{\mathrm{G} 93 \mathrm{~A}} \mathrm{mESC}$ line was previously analyzed in vitro under normal conditions [21]. Here, we investigate their survival in normal conditions and under oxidative stress and the effect of bNCSCs on SOD $1^{\mathrm{G} 93 \mathrm{~A}} \mathrm{MN}$ survival. Generation of MNs from mESCs results also in abundant generation of astrocytes. These cells express glutamate aspartate transporter (GLAST) and can be identified by antiGLAST antibodies [22]. To exclude the negative effect from surrounding SOD $1^{\mathrm{G} 93 \mathrm{~A}}$ astrocytes on $\mathrm{SOD} 1^{\mathrm{G} 93 \mathrm{~A}} \mathrm{MNs}$, we used magnetic activated cell sorting (MACS) to eliminate GLAST-positive cells from SOD $1^{\mathrm{G} 93 \mathrm{~A}}$ mESC cultures. To compare the effect of bNCSCs on SOD $1^{\mathrm{G} 93 \mathrm{~A}} \mathrm{MN}$ survival with $\mathrm{mESC}$ derived astrocytes, we used astrocytes differentiated from a non-SOD1 mutated glial fibrillary acidic protein (GFAP)::CD14 mESC line [23].

Our findings show that bNCSCs exert a significant survival promoting effect on co-cultured and co-implanted SOD1 ${ }^{\mathrm{G} 93 \mathrm{~A}}$ MNs.

\section{Material and methods}

\section{Mouse embryonic stem cell (mESC) cultures}

Mouse embryonic stem cell (mESC) lines harboring human wild type SOD1 (SOD1 ${ }^{\mathrm{WT}}$ ) or mutant SOD1 (SOD1 ${ }^{\mathrm{G} 93 \mathrm{~A}}$ ) were a kind gift from Dr. Kevin Eggan (Harvard Stem Cell Institute). The risk of tumor formation for implanted cells from low passages is minimal. These cell lines carry green fluorescent protein (GFP) under the control of the promoter for the MN specific transcription factor HB9 (HB9::GFP cells) [21]. We used the SOD $1^{\mathrm{WT}}$ and $\mathrm{SOD} 1^{\mathrm{G} 93 \mathrm{~A}} \mathrm{mESC}$ lines to derive $\mathrm{GFP}^{+} \mathrm{MNs}$.

For MN differentiation, a previously published protocol with small modifications was used [24]. Cells were cultured in ADFNB medium consisting of Advanced D-MEM/ F12:Neurobasal (1:1), 1x GlutaMAX supplement (Invitrogen), 1x B27 supplement (Invitrogen), 1x N2 supplement (Invitrogen), $0.1 \mathrm{mM}$ 2-mercaptoethanol (Sigma) to form embryoid bodies (EBs), and supplemented with $0.1 \mu \mathrm{M}$ of retinoic acid (RA, Sigma) and $0.5 \mu \mathrm{M}$ of sonic hedgehog (Shh) agonist Ag1.3 (Curis) every other day. After 7 days of pre-differentiation, EBs were subjected to MACS (see below), and thereafter either cultured alone, co-cultured with bNCSCs, or with mESC-derived astrocytes.

For in vitro $\mathrm{MN}$ differentiation, EBs were enzymatically dissociated with TrypLETM Express (Gibco) and seeded on pre-coated coverslips with $0.01 \%$ poly-1-ornithine (Sigma) followed by $10 \mu \mathrm{g} / \mathrm{mL}$ laminin (Sigma). Cells were seeded at a density of $5 \times 10^{4}$ cells/coverslip in 24 well plates with ADFNB cell medium supplemented with $10 \mathrm{ng} / \mathrm{mL}$ of CNTF (Miltenyi Biotec) and GDNF (Miltenyi Biotec). 50\% of the medium was replaced with fresh medium every other day until the cultures were fixed in $4 \%$ paraformaldehyde in phosphate buffered saline (PBS; $137 \mathrm{mM} \mathrm{NaCl}, 2.7 \mathrm{mM} \mathrm{KCl}, 100 \mathrm{mM}$ $\mathrm{Na}_{2} \mathrm{HPO}_{4}, 18 \mathrm{mM} \mathrm{KH}_{2} \mathrm{PO}_{4}$ ) at the indicated time points.

\section{bNCSC culture}

bNCSCs were generated from transgenic mice harboring red fluorescent protein (RFP) under the universal actin promoter [25] according to previously published protocols [15, 26]. Neurospheres from passages 4 to 5 were trypsinized to obtain single cell suspensions for MACS for subsequent co-culture and co-implantation with SOD $1{ }^{\mathrm{G} 93 \mathrm{~A}}$ MNs.

\section{Derivation of astrocytes from GFAP::CD14 mESC culture}

Astrocytes were generated from GFAP::CD14 mESCs (kind gift from Dr. Ivo Lieberam, Kings College, London), using MACS as has been previously described [23] with minor modifications. At day 7 of differentiation, the EBs were replated into T75 flasks (Sarstedt) pre-coated with $10 \mu \mathrm{g} / \mathrm{mL}$ laminin and cultured until day 12 in ADFNB medium. The monolayer formed by EBs was treated with TrypLETM Express on day 12 and a single cell suspension was prepared for MACS. Anti-CD14 antibody conjugated with magnetic microbeads was used according to the manufacturers protocol (Miltenyi Biotec). 


\section{Magnetic activated cell sorting (MACS)}

Anti-GLAST (ACSA-1) antibodies were used for MACS according to the manufacturers protocol (Miltenyi Biotec). bNCSCs and GFAP::CD14 EBs were subjected to MACS to obtain astrocyte cultures. SOD $1^{\mathrm{G} 93 \mathrm{~A}} \mathrm{EBs}$ were subjected to MACS using anti-GLAST to deplete SOD $1{ }^{\mathrm{G} 93 \mathrm{~A}} \mathrm{MN}$ cultures from SOD $1^{\mathrm{G} 93 \mathrm{~A}}$ astrocytes.

Culture suspensions containing around $3 \times 10^{6}$ cells were labeled with anti-GLAST antibodies. Thereafter, anti-mouse IgG magnetic microbeads (Miltenyi Biotec) were applied to the cells for 15 minutes at $4{ }^{\circ} \mathrm{C}$. Cells were re-suspended in MACS buffer (Miltenyi Biotec) and the cell suspension was loaded onto a MACS separation column (Miltenyi Biotec) and placed in the magnetic field of a MACS separator.

The column was rinsed three times with $0.5 \mathrm{~mL}$ of MACS buffer. In the case of the SOD $1^{\mathrm{G} 93 \mathrm{~A}}$ cell line, the GLASTpositive fraction was removed to minimize the influence of SOD $1^{\mathrm{G} 93 \mathrm{~A}}$ astrocytes on SOD $1^{\mathrm{G} 93 \mathrm{~A}}$ MNs. For bNCSCs and GFAP::CD14 EBs, the GLAST positive fractions were used for the experiments.

For differentiation assays, $5 \times 10^{4}$ of SOD $1^{\mathrm{G} 93 \mathrm{~A}}$ cells were seeded on $0.01 \%$ poly-1-ornithine and $10 \mu \mathrm{g} / \mathrm{mL}$ laminin coated coverslips. In case of co-cultures, around $2 \times 10^{4}$ bNCSCs or GFAP ::CD14 mESC-derived astrocytes were seeded first followed by SOD ${ }^{\mathrm{G} 93 \mathrm{~A}}$ MNs.

\section{Oxidative stress assay}

Oxidative stress was induced by hydrogen peroxide $\left(\mathrm{H}_{2} \mathrm{O}_{2}\right)$ in SOD $1{ }^{\text {WT }}$ MNs and SOD $1{ }^{\mathrm{G} 93 \mathrm{~A}}$ MNs plated alone or together with bNCSCs. In addition, bNCSCs were treated alone with $\mathrm{H}_{2} \mathrm{O}_{2}$ at similar concentrations to test their survival capacity under these conditions. On day 4 of differentiation assay, $\mathrm{H}_{2} \mathrm{O}_{2}(60 \mu \mathrm{M}, 150 \mu \mathrm{M}, 300 \mu \mathrm{M})$ was added for 3 hours to the cultures. Thereafter, the coverslips were fixed and analyzed for MN or bNCSC survival (GFP-positive or RFPpositive cells, respectively). For each condition at least three experiments were performed.

\section{Animals}

Transplantations were performed in Crl:NU(NCr)-Foxn1nu (nude; nu/nu) NMRI adult male mice $(n=12)$, (body weight 25-35 g; Möllegaard and Bomholgard Breeding and Research Centre, M\&B A/S, Bomholt, Denmark, http://www.taconic. com). The serial sections were from the spinal cords of six animals - three of which received bNCSCs and SOD1 ${ }^{\mathrm{G} 93 \mathrm{~A}}$ $\mathrm{MN}$ precursors (treatment group) and three only $\mathrm{SOD} 1^{\mathrm{G} 93 \mathrm{~A}}$ $\mathrm{MN}$ precursors (control group) - were analyzed under confocal microscope for MN survival and glial response. All animal experiments were approved by the Local Ethical Committee for Animal Experimentation, Uppsala, as required by Swedish Legislation and in accordance with European Union Directives.

\section{Surgery}

The animals were anesthetized by spontaneous inhalation of Isoflurane. After onset of anesthesia the mouse was placed on its stomach on a heating pad $\left(36^{\circ} \mathrm{C}\right)$ and the skin cleaned with ethanol $(70 \%)$. Following a procedure previously established in rats [27], an incision was made in the midline of the neck skin and local anesthetic (Xylocain $\odot, 10 \mathrm{mg} / \mathrm{ml}$ ) applied to the wound. After blunt dissection of the superficial and deep back muscles, the laminae of the cervical vertebrae were exposed. The vertebra prominens $(\mathrm{C} 7)$ was held fixed with a pair of forceps, a partial laminectomy was made of vertebrae $\mathrm{C} 3$ to $\mathrm{C} 5$, and the exposed meninges were gently opened. $4 \mu \mathrm{L}$ (2 injections of $2 \mu \mathrm{L}$ each, around 50000 cells per mouse) of equal proportion of bNCSCs and SOD $1^{\mathrm{G} 93 \mathrm{~A}} \mathrm{MN}$ precursors were injected into the left spinal cord using a Hamilton syringe with a metal needle (26 gauge) attached to a stereotactic frame and connected to an infusion pump (KD Scientific Legato 130). For the control group an equal amount of cells containing only SOD ${ }^{\mathrm{G} 93 \mathrm{~A}} \mathrm{MN}$ precursors were injected. The needle was kept in place for 2 minutes before removal. The wound was closed in layers using ethilon nylon suture 6.0 and 4.0, respectively. The animals were given $50 \mu \mathrm{l}$ buprenorphine (Temgesic@) subcutaneously every 12 hours for 3 days after the operation.

Seven days after surgery the animals were re-anesthetized with an intraperitoneal injection of a mixture of ketamine, xylazine and acepromazine [28], and perfused via the left ventricle with warm saline solution $\left(\sim 38{ }^{\circ} \mathrm{C}\right)$ followed by a cold $\left(\sim 4{ }^{\circ} \mathrm{C}\right)$ fixative solution consisting of $4 \%$ formaldehyde (vol/vol), 14\% saturated picric acid (wt/vol) in phosphate buffered saline (PBS; pH 7.35-7.45). The relevant part of the cervical spinal cord was removed, placed in fixative solution for 4 hours, and thereafter cryoprotected overnight in PBS containing $15 \%$ sucrose. The following day the tissue was placed in TissueTech ${ }^{\mathrm{TM}}$ and frozen in liquid nitrogen. Transverse sections $(14 \mu \mathrm{m})$ were cut on a cryostat, collected on SuperFrost ${ }^{\mathrm{TM}}$ Plus slides (Menzel-Gläser, Braunschweig, Germany), and processed for immunohistochemistry and microscopic analysis as described below.

\section{Immunohistochemistry}

Cells were fixed in $4 \%$ phosphate-buffered paraformaldehyde at room temperature (RT) for 5 minutes, washed and left in blocking solution ( $1 \%$ bovine serum albumin, $0.3 \%$ Triton $\mathrm{X}-100$ and $0.1 \% \mathrm{NaN}_{3}$ in PBS) for 60 minutes, and then incubated with primary antibodies overnight at $4{ }^{\circ} \mathrm{C}$, followed by the appropriate secondary antibodies for 1 hour at RT (Table 1). During the final wash, the cells were incubated with 
Table 1 Antibodies used in the study

\begin{tabular}{lllll}
\hline Antigen & Host & Catalog number & Source & Dilution \\
\hline Primary & & & & \\
Human SOD1 misfolded & Mouse & MM-0070-2 & Medimabs & $1: 100$ \\
GFAP & Rabbit & $2016-04$ & Dako & $1: 500$ \\
Iba1 & Rabbit & $019-19741$ & Wako & $1: 500$ \\
Beta-3-tubulin & Mouse & $32-2600$ & Invitrogen & $1: 500$ \\
ACSA-1 (GLAST) & Mouse & $130-095-822$ & Miltenyi Biotec & $1: 100$ \\
SOX2 & Goat & Sc-17320 & Santa Cruz & $1: 200$ \\
GFP-FITC & Goat & ab6662 & Abcam & $1: 250$ \\
Secondary & & & & $1: 500$ \\
Alexa 647 & Donkey $\alpha$ mouse & A31571 & Invitrogen & $1: 500$ \\
Alexa 647 & Donkey $\alpha$ rabbit & A31573 & Invitrogen & $1: 200$ \\
FITC & Donkey $\alpha$ goat & $705-095-147$ & Jackson ImmunoResearch & $1: 100$ \\
AMCA 350 & Donkey $\alpha$ rabbit & $711-155-152$ & Jackson ImmunoResearch & $1: 500$ \\
Cy3 & Donkey $\alpha$ mouse & $715-165-151$ & Jackson ImmunoResearch & 1 . \\
\hline
\end{tabular}

Hoechst 33342 (1:10000; Invitrogen) to label cell nuclei, and then mounted on a glass slide for analysis. bNCSC neurospheres were fixed for 30 minutes, immersed in $15 \%$ sucrose overnight, cryosectioned the next day and sections processed for immunohistochemistry.

Transverse sections from the C3-5 spinal cord were preincubated with blocking solution for $1 \mathrm{hr}$ at RT and then incubated overnight at $4{ }^{\circ} \mathrm{C}$ with primary antibodies for the astroglial marker GFAP or microglia/macrophage marker Ibal followed by the appropriate secondary antibodies and anti-GFP-FITC for 1 hour at RT (Table 1).

\section{Microscopy and cell counting}

Cells on coverslips and spinal cord cryosections were captured using a $20 \times$ objective (NA 0.75) of a Nikon Eclipse E800 epifluorescence microscope equipped with a Nikon DXM1200F CCD camera. For cultured cells, GFP and RFP positive cells were counted manually for each condition. GFP positive cells were counted in every 5 th cryosection along the length of the transplant area (ranging from $\sim 0.8$ to $1.5 \mathrm{~mm}$ along the cranial-caudal axis between animals). Sections were analysed using a Zeiss LSM700 or a Zeiss LSM780 confocal laser scanning microscope. Images were captured using a LD LCI Plan-Apochromat 20x (NA 0.8) or a LD C-Apochromat 40x W Corr (NA 1.1) objective.

\section{Statistical Analysis}

Datasets for oxidative stress and survival assays were analyzed using two-way ANOVA followed by the Bonferroni multiple comparisons tests. MN survival was analyzed using a two-tailed Students t-test. All statistical analyses were performed in GraphPad Prism 5.04. The confidence interval was stated at the $95 \%$ confidence level, placing statistical significance at $\mathrm{p}<0.05$.

\section{Results}

\section{Improved survival of SOD1 ${ }^{\text {G93A }}$ MNs in vitro}

Both SOD $1^{\text {WT }}$ and SOD $1^{\mathrm{G} 93 \mathrm{~A}} \mathrm{mESC}$ lines formed EBs with abundant expression of $H B 9:: \mathrm{GFP}$ and gave rise to $\mathrm{GFP}^{+} \mathrm{MN}$ precursors in culture (Supplementary Fig. 1).

bNCSCs neurospheres abundantly expressed RFP, the neural crest stem cell marker SOX2 and GLAST (after MACS purification), and continued to express RFP in differentiation assay in co-culture and co-implants (Supplementary Figs. 2, 3 and 4).

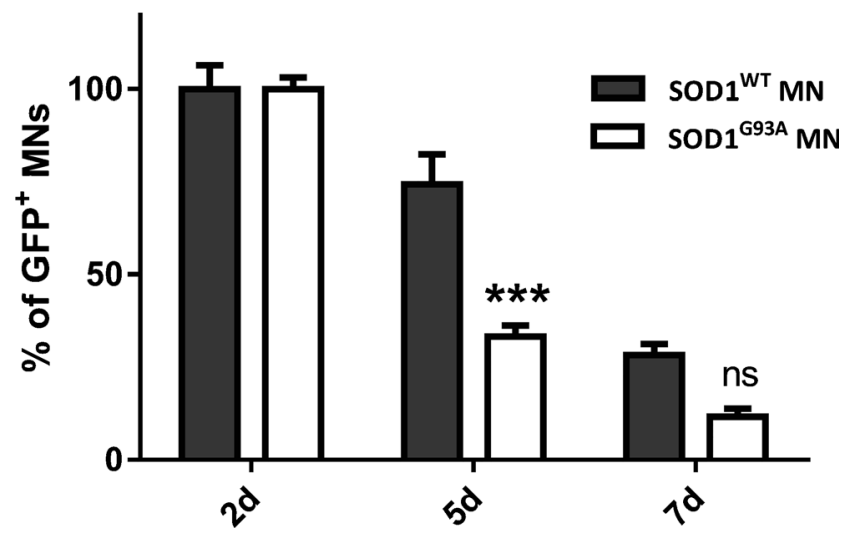

Fig. 1 Survival of SOD $1^{\mathrm{WT}}$ and SOD $1^{\mathrm{G} 93 \mathrm{~A}} \mathrm{MNs}$ in vitro. The SOD1 ${ }^{\mathrm{G} 93 \mathrm{~A}}$ cell line shows a reduced MN survival compared to the SOD ${ }^{\mathrm{WT}}$ cell line between days 2 and 7 . Asterisks indicate the level of statistical significance by two-way ANOVA followed by Bonferroni multiple comparison test $(* * * p<0.001)$. Data shown is in mean \pm SEM of three independent experiments 
The poor survival of SOD $1^{\mathrm{G} 93 \mathrm{~A}} \mathrm{MNs}$ in vitro has been compared to MNs derived from the HB9::GFP cell line in a previous study [21]. Here we compare the survival of SOD $1{ }^{\mathrm{G} 93 \mathrm{~A}}$ MNs with SOD ${ }^{\mathrm{WT}}$ MNs to confirm that the reduced survival is due to the SOD1 ${ }^{\mathrm{G} 93 \mathrm{~A}}$ mutation. Cells from both cultures were subjected to differentiation assay and $\mathrm{GFP}^{+}$ MNs were counted after 2, 5 and 7 days of differentiation. The number of MNs declined more rapidly in SOD $1^{\mathrm{G} 93 \mathrm{~A}}$ cultures at day 5 of differentiation $(\mathrm{p}<0.001)$ (Fig. 1).

During MN differentiation from mESCs, a population of astrocytes is also present. Previous studies have shown a negative effect of SOD $1^{\mathrm{G} 93 \mathrm{~A}}$ astrocytes on MNs [21]. We therefore examined if a reduction of the astrocyte population in SOD $1^{\mathrm{G} 93 \mathrm{~A}}$ cultures will improve MN survival and if coculture with bNCSCs, or with GFAP::CD14 astrocytes will improve the survival of SOD $1^{\mathrm{G} 93 \mathrm{~A}}$ MNs.

After reduction of the astrocyte population in $\mathrm{SOD} 1^{\mathrm{G} 93 \mathrm{~A}}$ cultures there was an approximate $75 \%$ increase in the number of SOD ${ }^{\mathrm{G} 93 \mathrm{~A}}$ MNs 12 hours after purification compared to non-purified cell cultures (Fig. $2 \mathrm{a} ; \mathrm{p}<0.01$ ). The survival of SOD $1{ }^{\mathrm{G} 93 \mathrm{~A}} \mathrm{MNs}$ was significantly increased in co-culture with bNCSC by day 7 (Fig. $2 \mathrm{~b} ; \mathrm{p}<0.01$ and $\mathrm{p}<0.05$ ), whereas co-culture of SOD $1{ }^{\mathrm{G} 93 \mathrm{~A}} \mathrm{MNs}$ with GFAP::CD14 astrocytes did not affect MN survival (Fig. 2c).

We detected close contact between SOD $1^{\mathrm{G} 93 \mathrm{~A}} \mathrm{MNs}$ and bNCSCs, but did not observe immunoreactivity for misfolded SOD1 in bNCSCs, suggesting that aggregated SOD1 was not transferred from SOD $1{ }^{\mathrm{G} 93 \mathrm{~A}} \mathrm{MNs}$ to adjacent bNCSCs (Fig. 3).

\section{bNCSCs improve survival of SOD1 ${ }^{\text {G93A }}$ MNs in vitro under oxidative stress}

We compared the survival of SOD $1^{\mathrm{G} 93 \mathrm{~A}} \mathrm{MNs}$ and SOD $1^{\mathrm{WT}}$ MNs under oxidative stress. Survival of SOD $1{ }^{\mathrm{G} 93 \mathrm{~A}} \mathrm{MNs}$ was markedly decreased $(\mathrm{p}<0.01$ and $\mathrm{p}<0.05)$ compared to SOD $1{ }^{\mathrm{WT}} \mathrm{MNs}$, indicating that SOD $1{ }^{\mathrm{G} 93 \mathrm{~A}} \mathrm{MNs}$ are more susceptible than wildtype MNs to oxidative stress (Fig. 4a). Coculture of SOD $1{ }^{\mathrm{G} 93 \mathrm{~A}} \mathrm{MNs}$ with bNCSCs under oxidative stress showed a significant increase in SOD $1{ }^{\mathrm{G} 93 \mathrm{~A}} \mathrm{MN}$ survival compared to SOD1 ${ }^{\mathrm{G} 93 \mathrm{~A}}$ MNs cultured alone $(\mathrm{p}<0.001$ and $\mathrm{p}<0.05$, Fig. 4b).

We next tested if bNCSCs are susceptible to oxidative stress under similar oxidative stress conditions and found no effect of $\mathrm{H}_{2} \mathrm{O}_{2}$ exposure on the survival of bNCSCs in vitro (Supplementary Fig. 3).

\section{SOD1 ${ }^{\text {G93A }}$ MNs show increased survival in the presence of bNCSCs in vivo}

SOD1 ${ }^{\mathrm{G} 93 \mathrm{~A}}$ MNs alone or together with bNCSCs were implanted into the left spinal cord of nude mice, and the survival of implanted MNs was assessed one week after implantation. In all animals which received SOD $1{ }^{\mathrm{G} 93 \mathrm{~A}} \mathrm{MN}$ precursors together with bNCSCs, significantly more $\mathrm{GFP}^{+} \mathrm{SOD} 1^{\mathrm{G} 93 \mathrm{~A}}$ MNs were detected compared to animals that received SOD ${ }^{\text {G93A }}$ MN precursors alone (Student's t-test, $p<0.05$, Fig. 5a). The surviving MNs were located in the proximity of bNCSCs or localized as single cells in the spinal cord parenchyma (Fig. 5b,c). Immunolabeling with the astrocytic marker GFAP revealed that bNCSCs differentiated primarily to GFAP positive cells (Fig. 5e).

The improved survival of MNs in the presence of bNCSCs after implantation prompted us to investigate if bNCSCs affect the glial response in the recipient spinal cord in the vicinity of implanted MN precursors. As expected, there was an increased immunolabeling for GFAP and Ibal from the minor injury at the injection site, but these changes were similar in the two experimental groups (Fig. 5d,e). However. the glial response for GFAP and Ibal within the area where bNCSCs

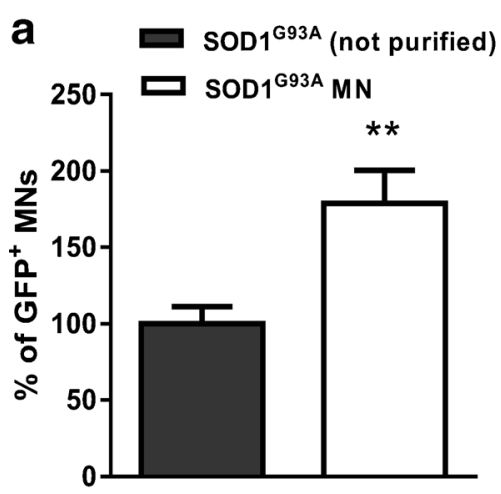

b

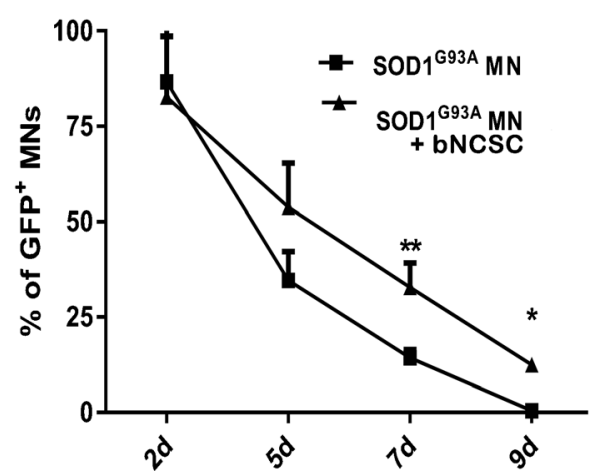

c

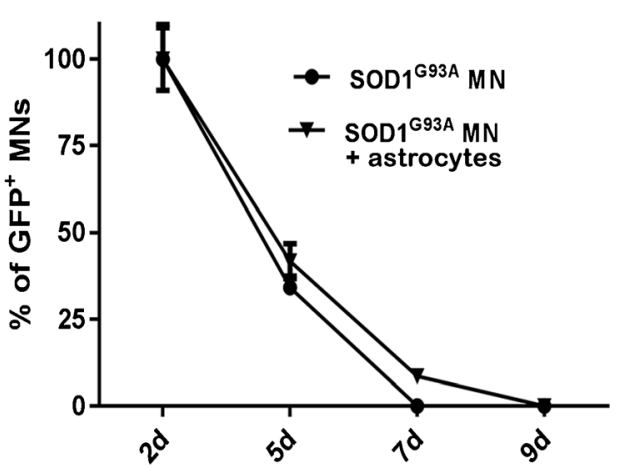

Fig. 2 Increased survival of SOD1 ${ }^{\mathrm{G} 93 \mathrm{~A}} \mathrm{MNs}$ in vitro by removal of SOD1 ${ }^{\mathrm{G} 93 \mathrm{~A}}$ astrocytes and addition of bNCSC. Removal of astrocytes from SOD $1^{\mathrm{G} 93 \mathrm{~A}}$ cell cultures results in an increased number of SOD1 ${ }^{\mathrm{G} 93 \mathrm{~A}} \mathrm{MNs}$ (a). Survival of SOD $1^{\mathrm{G} 93 \mathrm{~A}} \mathrm{MNs}$ increased when cocultured with bNCSCs (b). SOD $1^{\text {G93A }}$ MN survival showed no improvement when co-cultured with GFAP::CD14 astrocytes (c). Asterisks indicate the level of statistical significance by two-tailed Student's test (a) or two-way ANOVA (b) $\left(* * \mathrm{p}<0.01,{ }^{*} \mathrm{p}<0.05\right)$. Data shown is in mean $\pm \mathrm{SEM}$ of three independent experiments 

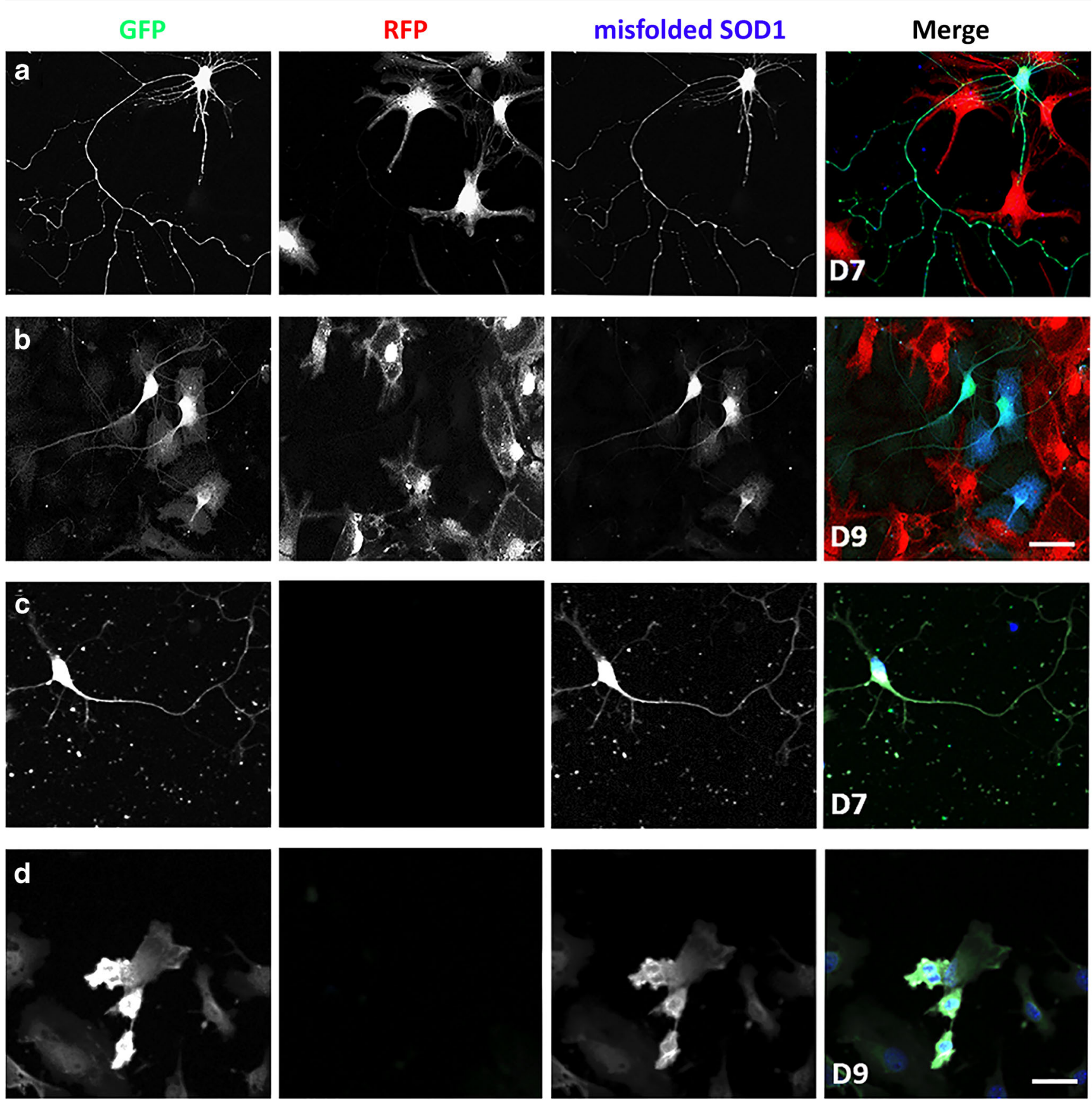

Fig. 3 SOD $1^{\text {G93A }} \mathrm{MNs}$ in the presence or absence of bNCSCs in vitro. Co-cultured SOD1 ${ }^{\mathrm{G} 93 \mathrm{~A}}$ cells (GFP) and bNCSCs (RFP) display close contact on day 7 (a) and 9 (b), misfolded SOD1 was only detected in

were located seemed reduced compared to adjacent areas lacking bNCSCs (Fig. 6a,b).

\section{Discussion}

There is an urgent need for novel therapeutic strategies with enhanced effect for ALS patients. Here we show that bNCSCs exert a significant survival promoting effect on $\mathrm{SOD} 1^{\mathrm{G} 93 \mathrm{~A}}$ $\mathrm{MN}$ in vitro as well as after co-implantation to the spinal cord.

SOD $1^{\mathrm{G} 93 \mathrm{~A}} \mathrm{MNs}$. SOD $1^{\mathrm{G} 93 \mathrm{~A}} \mathrm{MNs}$ cultured alone show reduced survival and the presence of misfolded SOD1 on day 7 (c) and day 9 (d). Scale bar: $50 \mu \mathrm{m}$

Previously, we detected several beneficial effects of bNCSCs on co-cultured and co-transplanted cells. Thus, bNCSCs strongly increase proliferation of insulin producing beta-cells in co-transplants of mouse pancreatic islets in streptozotocin diabetic mice [19, 29], and in co-culture with beta-cells [17]. bNCSCs protect insulin-producing cells from cytokine induced apoptosis in vitro [18], an effect which appears to require direct bNCSC- cell contact through catenin-cadherin junctions [30]. Co-implantation of bNCSCs with mouse and human pancreatic islets improves their survival after 
a

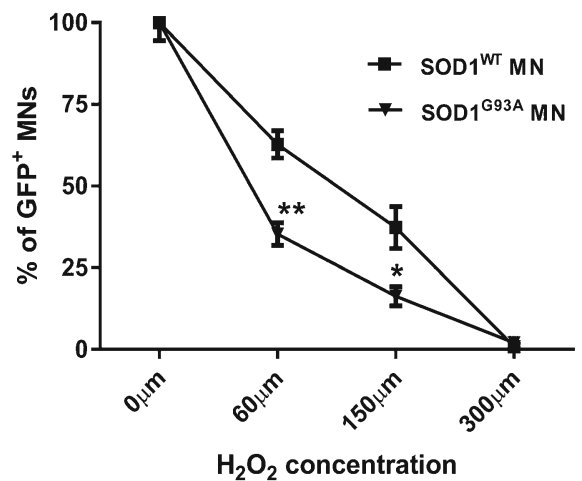

Fig. 4 Effect of hydrogen peroxide $\left(\mathrm{H}_{2} \mathrm{O}_{2}\right)$ on $\mathrm{SOD} 1{ }^{\mathrm{G} 93 \mathrm{~A}}$ MN survival in vitro. Survival of SOD $1^{\mathrm{G} 93 \mathrm{~A}} \mathrm{MNs}$ was reduced compared to SOD $1^{\mathrm{WT}}$ MNs under oxidative stress (a). Survival of SOD $1{ }^{\mathrm{G} 93 \mathrm{~A}} \mathrm{MNs}$ increased when co-cultured with bNCSCs (SOD1 ${ }^{\mathrm{G} 93 \mathrm{~A}} \mathrm{MNs}+$ bNCSCs) compared

transplantation and increases beta-cell proliferation, vascularization of transplants and their re-innervation [29]. We also found their survival supporting effect in spinal cord slice cultures exposed to excitotoxic stress (unpublished observation).

The conditions for implanting healthy supportive cells into the spinal cord of ALS patients imply that these cells will have not only to survive in the harmful ALS environment, but also exert beneficial effects on diseased MNs. For this reason we have tested if bNCSCs are susceptible to oxidative stress and found that they are resistant to exposure to hydrogen peroxide in concentrations which significantly impair survival of SOD $1^{\mathrm{G} 93 \mathrm{~A}}$ MNs. We next examined whether bNCSCs are "contaminated" with misfolded SOD1 from co-cultured SOD $1^{\mathrm{G} 93 \mathrm{~A}}$ MNs. ALS appears to begin focally at a random location and progresses contiguously through two distinct types of neuroanatomic propagation: contiguous propagation through the extracellular matrix independent of synaptic connections, and network propagation, which is dependent on synaptic connections [31]. In many neurodegenerative disorders misfolded proteins appear to contribute to disease progression [32]. Thus, the presence of misfolded SOD1 may contribute to disease propagation in some forms of ALS [33]. We detected immunoreactivity for misfolded SOD1 in SOD $1^{\text {G93A }}$ MNs generated from SOD $1^{\mathrm{G} 93 \mathrm{~A}}$ mESCs. Although astrocytes co-cultured with SOD $1^{\mathrm{G} 93 \mathrm{~A}} \mathrm{MNs}$ have been reported to be "contaminated" with aggregated SOD1 [34], we did not detect aggregated SOD1 in bNCSCs, suggesting that they are resistant to relocation of misfolded SOD1. Thus, bNCSCs display properties in vitro that may be useful for disease modifying cell therapy in ALS.

We explored these properties in co-cultures of bNCSCs with SOD $1{ }^{\text {G93A }}$ MNs subjected to oxidative stress, and demonstrated significantly increased SOD $1^{\mathrm{G} 93 \mathrm{~A}} \mathrm{MN}$ survival compared to untreated SOD $1^{\mathrm{G} 93 \mathrm{~A}} \mathrm{MN}$ cultures. In agreement with previous studies [11], we found that depletion of the astrocyte population from $\mathrm{SOD} 1^{\mathrm{G} 93 \mathrm{~A}}$ cultures, increases $\mathrm{MN}$

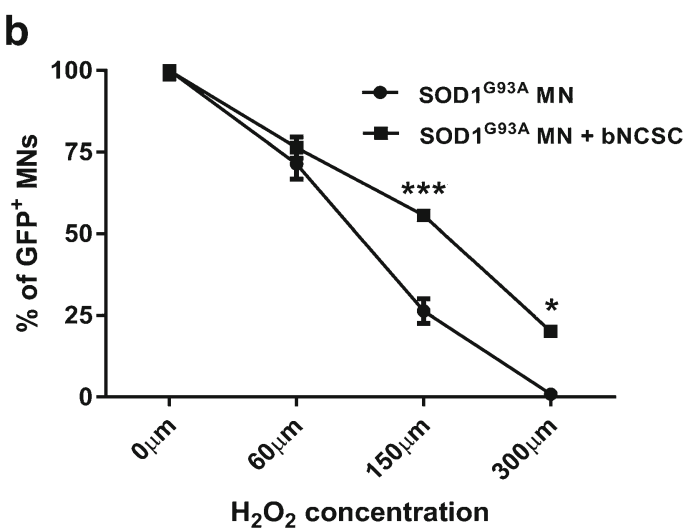

to when cultured alone ( $\mathrm{SOD} 1^{\mathrm{G} 93 \mathrm{~A}} \mathrm{MN}$ ) (b). Asterisks indicate level of statistical significance by two-way ANOVA followed by Bonferroni multiple comparison test $(* * * \mathrm{p}<0.001, * * \mathrm{p}<0.01, * \mathrm{p}<0.05)$. Data shown is in mean \pm SEM of three independent experiments

survival. The addition of bNCSCs, but not healthy astrocytes, to these cultures further improved the survival of SOD 1 G93A MNs under both normal and oxidative stress conditions. This finding provides additional evidence for the potency of bNCSCs in supporting diseased SOD $1^{\mathrm{G} 93 \mathrm{~A}}$ MNs. The improved SOD $1{ }^{\mathrm{G} 93 \mathrm{~A}} \mathrm{MN}$ survival coincided with the presence of direct contacts between bNCSCs and SOD $1^{\mathrm{G} 93 \mathrm{~A}} \mathrm{MNs}$, suggesting that the positive effect of bNCSCs might be mediated through intercellular connections, as was shown previously in bNCSC-beta-cell cultures [29]. We have also shown that bNCSCs produce a broad range of trophic factors, as well as Wnt-1 and matrix metalloproteinases [35]. This trophic capacity, in co-operation with direct cell-cell interaction, may explain the survival promoting effects of bNCSCs on SOD $1{ }^{\mathrm{G} 93 \mathrm{~A}} \mathrm{MNs}$ under stressful conditions in vitro.

Pre-differentiated neural cells are particularly vulnerable during the initial period after implantation into the central nervous system. At this stage environmental conditions that support survival and differentiation of implanted cells are likely to be critical for their subsequent integration into neural circuits and long-term survival. We therefore focused on the viability of SOD $1^{\mathrm{G} 93 \mathrm{~A}} \mathrm{MNs}$ alone, or in combination with bNCSCs, during the first week of their implantation. One week after implantation of SOD $1^{\mathrm{G} 93 \mathrm{~A}} \mathrm{MN}$ precursors to the spinal cord, only few surviving SOD1 ${ }^{\text {G93A }}$ MNs were found. Survival of SOD1 ${ }^{\mathrm{G} 93 \mathrm{~A}} \mathrm{MNs}$ was, however, significantly increased when co-implanted with bNCSCs, despite the fact that twice as many SOD1 ${ }^{\mathrm{G} 93 \mathrm{~A}}$ $\mathrm{MN}$ precursors were implanted alone compared to the number of SOD $1^{\mathrm{G} 93 \mathrm{~A}} \mathrm{MN}$ precursors co-implanted with bNCSCs. These findings show that bNCSCs create environmental conditions for SOD1 ${ }^{\mathrm{G} 93 \mathrm{~A}} \mathrm{MNs}$, which support their survival in the spinal cord.

Inflammatory components have been implicated in the neurodegeneration associated with ALS [36]. As expected, the injection procedure resulted in a local microglial and 
a

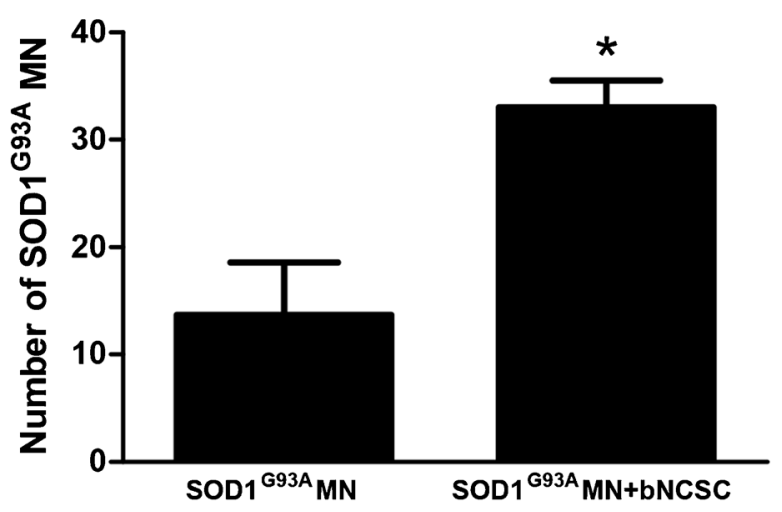

d
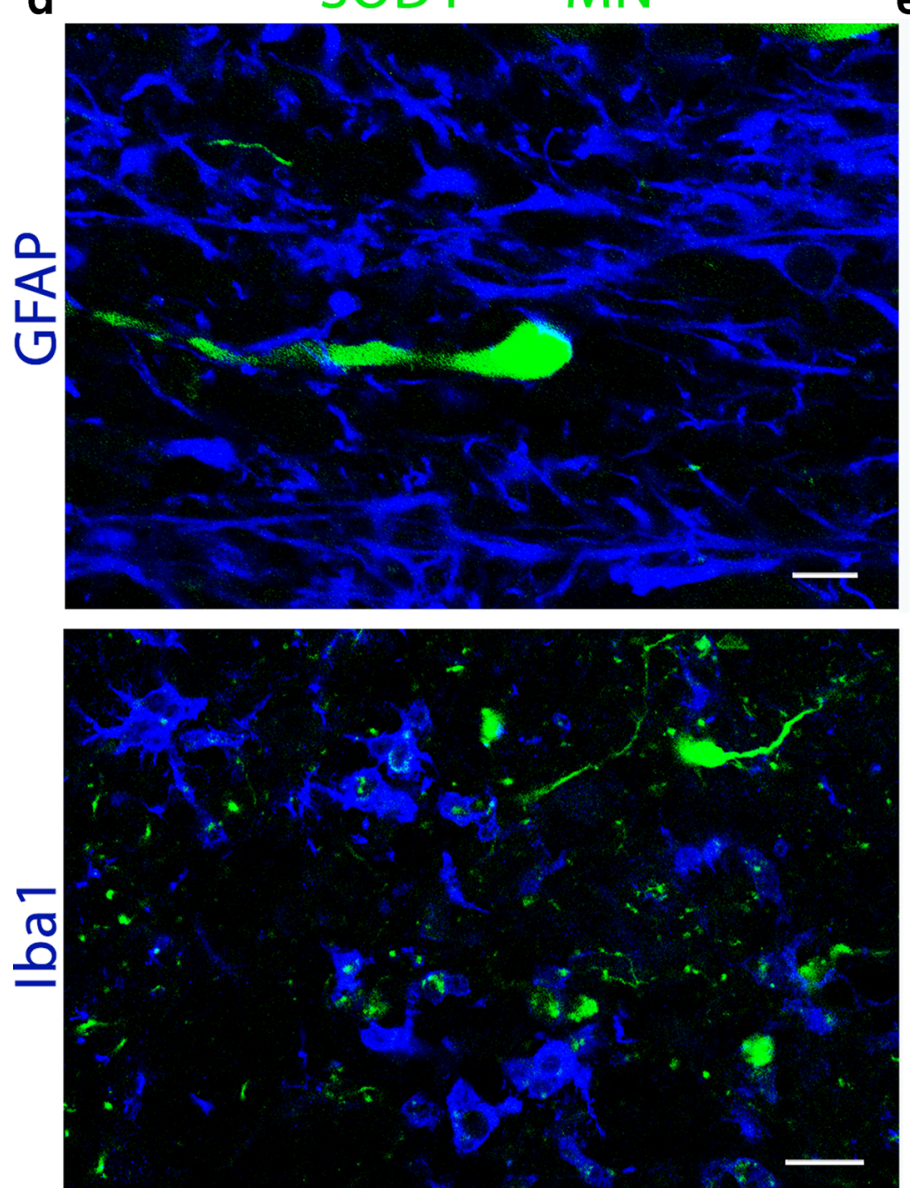

Fig. 5 Increased survival of SOD $1^{\mathrm{G} 93 \mathrm{~A}} \mathrm{MN}$ after co-implantation with bNCSC to the spinal cord of mice. One week after implantation, SOD1 ${ }^{\text {G93A }}$ MN co-implanted with bNCSC showed significantly increased survival compared to SOD $1^{\mathrm{G} 93 \mathrm{~A}} \mathrm{MN}$ implanted alone. Asterisks indicate the level of statistical significance by two-tailed Student's t-test $(* \mathrm{p}<0.05)$. Data shown is in mean \pm SEM of three animals per condition (a). SOD $1^{\mathrm{G} 93 \mathrm{~A}} \mathrm{MNs}$ when implanted alone are located as single cells in the spinal cord parenchyma (b). When
C

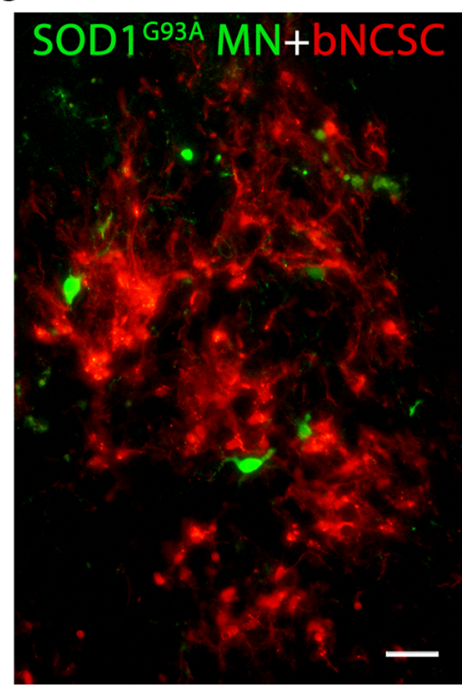

e SOD1 ${ }^{\text {G93A }} \mathrm{MN}+\mathrm{bNCSC}$
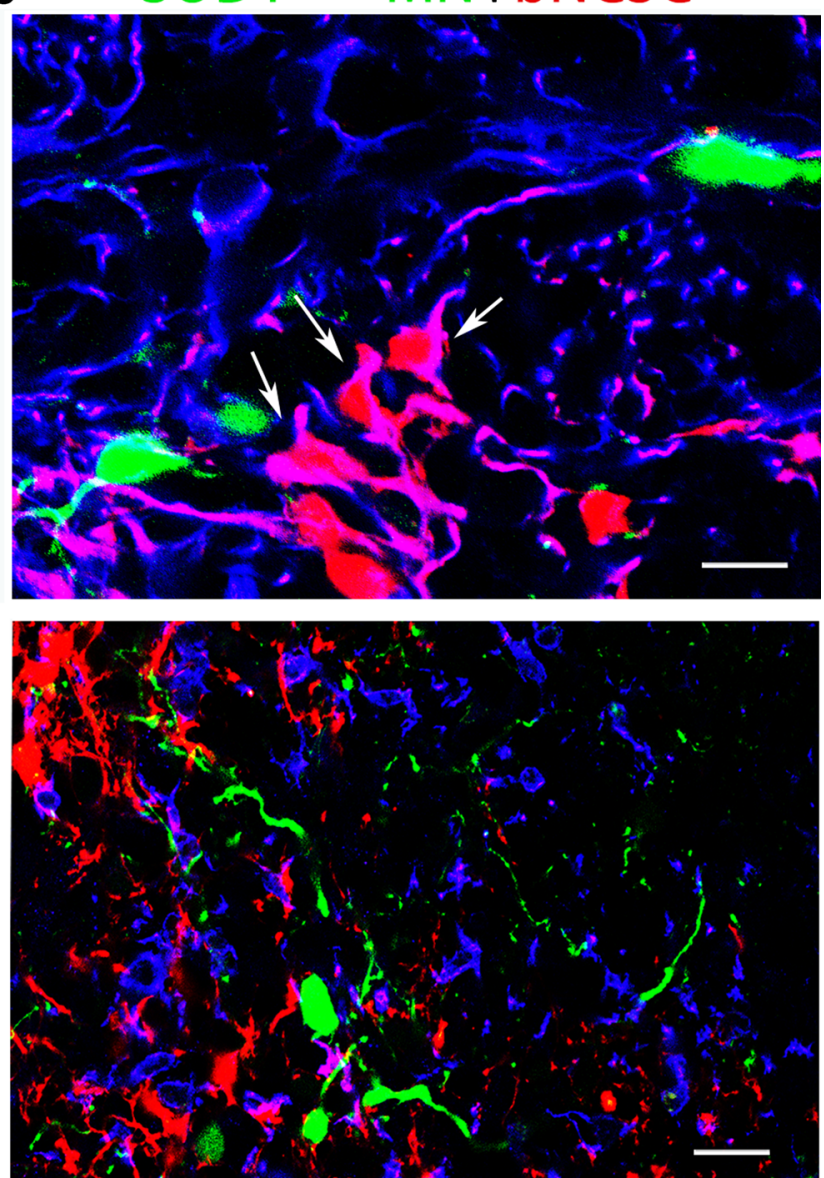

implanted together with bNCSCs, SOD1 ${ }^{\mathrm{G} 93 \mathrm{~A}} \mathrm{MNs}$ can be found both spread out as single cells as well as in close proximity to bNCSCs (c). The injection site showed increased immunoreactivity for GFAP and Iba1 following implantation of either SOD1G93A MN alone (d) or coimplantation with bNCSCs (e). Arrows indicate bNCSCs differentiated to GFAP positive cells (e). Scale bars: b,c $25 \mu \mathrm{m}$; d,e $10 \mu \mathrm{m}$ for GFAP and $20 \mu \mathrm{m}$ for Iba1 

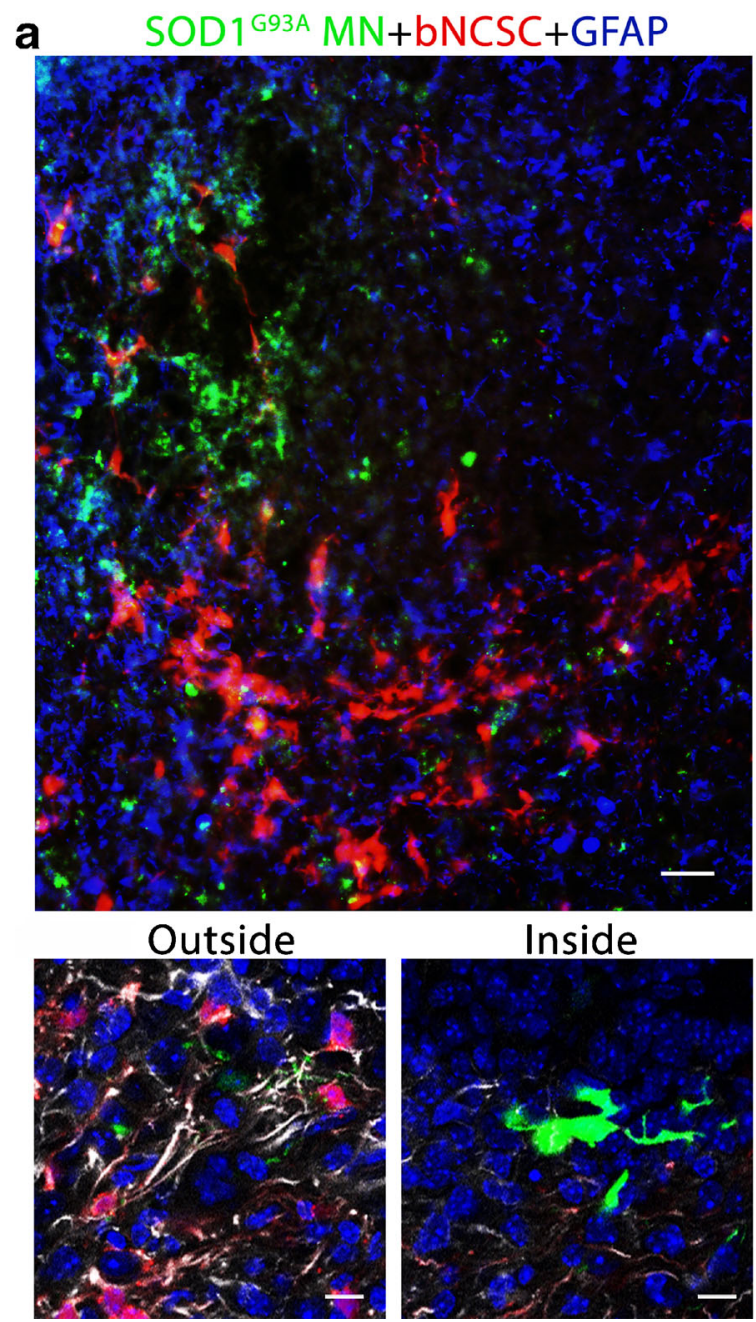

Fig. 6 Transplanted bNCSCs might diminish the local glial response following implantation. Spinal cord areas partially surrounded by bNCSC transplants showed decreased immunoreactivity for GFAP (a, inside) and Ibal (b, inside) and a high number of co-implanted SOD1 ${ }^{\mathrm{G} 93 \mathrm{~A}} \mathrm{MN}(\mathbf{a}, \mathbf{b})$. Overviews show GFAP and Iba1 in blue, high

astroglial response at the site of cell implantation, but this response did not differ between the two experimental conditions. However, when areas harboring implanted cells were analyzed, immunoreactivity for host microglia/macrophages and astrocytes appeared reduced where $\mathrm{SOD} 1^{\mathrm{G} 93 \mathrm{~A}}$ and bNCSCs were co-localized, suggesting that bNCSCs are able to attenuate the local inflammatory response associated with implanted SOD $1{ }^{\mathrm{G} 93 \mathrm{~A}}$ MNs. The survival support by bNCSCs may initially rely on direct cell-cell interactions at the site of cell implantation where bNCSCs and SOD $1{ }^{\mathrm{G} 93 \mathrm{~A}} \mathrm{MN}$ precursors intermingle during the injection procedure. However, the presence of $\mathrm{GFP}^{+} \mathrm{MNs}$ at a distance from bNCSCs and in the vicinity of the central canal one week after implantation indicates that some implanted SOD $1{ }^{\mathrm{G} 93 \mathrm{~A}} \mathrm{MN}$ precursors rapidly become independent of close contact with bNCSCs. Survival of migrated SOD $1^{\mathrm{G} 93 \mathrm{~A}}$ MNs may be supported by bNCSCderived diffusible molecules, such as vascular endothelial

\section{b SOD $1^{\mathrm{G} 93 \mathrm{~A}} \mathrm{MN+bNCSC+ \textrm {Iba } 1}$}
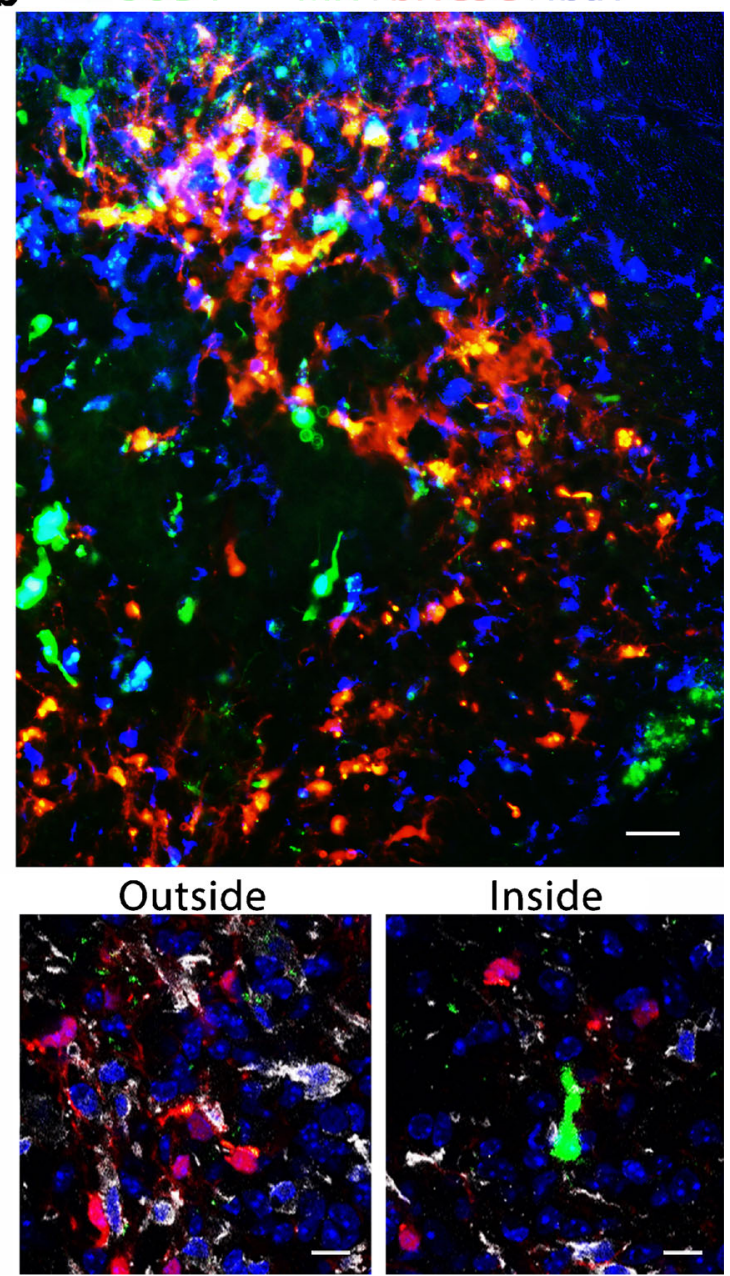

magnification confocal images show GFAP and Ibal in white and cell nuclei in blue for areas inside and outside the area of bNCSC transplantation. Scale bars: a,b $25 \mu \mathrm{m}$ for overviews and $10 \mu \mathrm{m}$ for high magnification images

growth factor (VEGF), brain-derived neurotrophic factor (BDNF), glial-derived neurotrophic factor (GDNF), and ciliary neurotrophic factor (CNTF) [35], all of which have trophic effects on MNs [37]. bNCSC-derived matrix metalloproteinase-2 and -9 (MMP-2 and -9) [36], which have been implicated in cell migration [38,39], may contribute to the migratory capacity of implanted SOD $1^{\mathrm{G} 93 \mathrm{~A}} \mathrm{MNs}$ to the spinal cord parenchyma and in some cases towards the central canal (Supplemental Fig. 4). The ependyma which surrounds this canal is a source of growth factors [40] and was previously designated as a stem cell region in the adult spinal cord [41]. Previous studies have shown that stem cells readily generate neurons when transplanted into neurogenic areas of the adult brain $[42,43]$. The survival of SOD $1^{\mathrm{G} 93 \mathrm{~A}} \mathrm{MN}$ precursors in the central canal area suggests that this is a region in the spinal cord with neurogenic properties, which are beneficial for the survival of implanted MN precursors. 
The ability of bNCSCs to promote vascularization of coimplanted tissue [29] may also have contributed to improved survival of co-implanted SOD $1^{\mathrm{G} 93 \mathrm{~A}}$ MNs. Previous studies have shown that ALS is associated with disruption of the blood-CNS-barrier (B-CNS-B) [44-46], a process that can contribute to the inflammatory response in areas affected by ALS. An interesting aspect in this context is whether the angiogenetic properties of bNCSCs in combination with their preferential post-implantation differentiation to healthy SOD $1^{\mathrm{G} 93 \mathrm{~A}}$ resistant astrocytes may contribute to the formation of new blood vessels with an intact B-CNS-B in the diseased spinal cord. Implantation of bNCSCs to animal models of ALS may clarify the potential of these cells to recover B-CNS-B.

In conclusion, we show that bNCSCs promote survival of $\mathrm{SOD} 1^{\mathrm{G} 93 \mathrm{~A}} \mathrm{MNs}$ in vitro and in vivo after co-implantation to the spinal cord. The beneficial effects by bNCSCs might be due to their resistance to oxidative stress and their neurotrophic and angiogenic support. These properties in combination with their resistance to SOD1 ${ }^{\mathrm{G} 93 \mathrm{~A}}$ aggregates make them interesting candidates for further investigations on novel therapeutic approaches to achieve long-term neuroprotection in animal models of ALS.

Acknowledgments We are grateful to Dr. Ivo Lieberam for providing us with the GFAP::CD14 cell line and for reading the manuscript, and to Dr. Kevin Eggan for the $H B 9::$ GFP cell lines. The study was supported by the Swedish Research Council (Project No 20716), under the frame of EuroNanoMed-II, Stiftelsen Olle Engkvist Byggmästare and Signhild Engkvists Stiftelse.

Required Author Forms Disclosure forms provided by the authors are available with the online version of this article.

\section{Compliance with Ethical Standards}

Conflict of interest The authors declare that they have no conflict of interest.

Open Access This article is distributed under the terms of the Creative Commons Attribution 4.0 International License (http:// creativecommons.org/licenses/by/4.0/), which permits unrestricted use, distribution, and reproduction in any medium, provided you give appropriate credit to the original author(s) and the source, provide a link to the Creative Commons license, and indicate if changes were made.

\section{References}

1. Carlesi C, Pasquali L, Piazza S, Lo Gerfo A, Caldarazzo Ienco E, Alessi R, et al. Strategies for clinical approach to neurodegeneration in Amyotrophic lateral sclerosis. Arch Ital Biol. 2011 Mar;149(1): 151-67.

2. Bellingham MC. A review of the neural mechanisms of action and clinical efficiency of riluzole in treating amyotrophic lateral sclerosis: what have we learned in the last decade? CNS Neurosci Ther. $2011 \mathrm{Feb} ; 17(1): 4-31$.
3. Kaur SJ, McKeown SR, Rashid S. Mutant SOD1 mediated pathogenesis of Amyotrophic Lateral Sclerosis. Gene. 2016 Feb 15;577(2):109-18.

4. Rojas F, Cortes N, Abarzua S, Dyrda A, van Zundert B. Astrocytes expressing mutant SOD1 and TDP43 trigger motoneuron death that is mediated via sodium channels and nitroxidative stress. Front Cell Neurosci. 2014;8:24.

5. Nagai M, Re DB, Nagata T, Chalazonitis A, Jessell TM, Wichterle $\mathrm{H}$, et al. Astrocytes expressing ALS-linked mutated SOD1 release factors selectively toxic to motor neurons. Nat Neurosci. 2007 May;10(5):615-22.

6. Di Giorgio FP, Boulting GL, Bobrowicz S, Eggan KC. Human embryonic stem cell-derived motor neurons are sensitive to the toxic effect of glial cells carrying an ALS-causing mutation. Cell Stem Cell. 2008 Dec 4;3(6):637-48.

7. Fritz E, Izaurieta P, Weiss A, Mir FR, Rojas P, Gonzalez D, et al. Mutant SOD1-expressing astrocytes release toxic factors that trigger motoneuron death by inducing hyperexcitability. J Neurophysiol. 2013 Jun;109(11):2803-14.

8. Papadeas ST, Kraig SE, O'Banion C, Lepore AC, Maragakis NJ. Astrocytes carrying the superoxide dismutase 1 (SOD1G93A) mutation induce wild-type motor neuron degeneration in vivo. Proc Natl Acad Sci USA. 2011 Oct 25;108(43):17803-8.

9. Haidet-Phillips AM, Hester ME, Miranda CJ, Meyer K, Braun L, Frakes A, et al. Astrocytes from familial and sporadic ALS patients are toxic to motor neurons. Nat Biotechnol. 2011 Aug 10;29(9): 824-8.

10. Meyer K, Ferraiuolo L, Miranda CJ, Likhite S, McElroy S, Renusch $\mathrm{S}$, et al. Direct conversion of patient fibroblasts demonstrates noncell autonomous toxicity of astrocytes to motor neurons in familial and sporadic ALS. Proc Natl Acad Sci USA. 2014 Jan 14;111(2): 829-32.

11. Yamanaka K, Chun SJ, Boillee S, Fujimori-Tonou N, Yamashita H, Gutmann DH, et al. Astrocytes as determinants of disease progression in inherited amyotrophic lateral sclerosis. Nat Neurosci. 2008 Mar;11(3):251-3.

12. Thangavelu SR, Tripathi PP, Arya U, Mishra HK, Subramaniam JR. ALS associated mutant SOD1 impairs the motor neurons and astrocytes and wild type astrocyte secreted-factors reverse the impaired motor neurons. Ann Neurosci. 2011 Apr;18(2):48-55.

13. Lepore AC, Rauck B, Dejea C, Pardo AC, Rao MS, Rothstein JD, et al. Focal transplantation-based astrocyte replacement is neuroprotective in a model of motor neuron disease. Nat Neurosci. 2008 Nov;11(11):1294-301.

14. Boucherie C, Schäfer S, Lavand'homme P, Maloteaux J-M, Hermans E. Chimerization of astroglial population in the lumbar spinal cord after mesenchymal stem cell transplantation prolongs survival in a rat model of amyotrophic lateral sclerosis. J Neurosci Res. 2009 Jul;87(9):2034-46.

15. Hjerling-Leffler $\mathrm{J}$, Marmigère $\mathrm{F}$, Heglind $\mathrm{M}$, Cederberg $\mathrm{A}$, Koltzenburg M, Enerbäck S, et al. The boundary cap: a source of neural crest stem cells that generate multiple sensory neuron subtypes. Development. 2005 Jun;132(11):2623-32.

16. Zujovic V, Thibaud J, Bachelin C, Vidal M, Deboux C, Coulpier F, et al. Boundary cap cells are peripheral nervous system stem cells that can be redirected into central nervous system lineages. Proc Natl Acad Sci USA. 2011 Jun 28;108(26):10714-9.

17. Grouwels G, Vasylovska S, Olerud J, Leuckx G, Ngamjariyawat A, Yuchi Y, et al. Differentiating neural crest stem cells induce proliferation of cultured rodent islet beta cells. Diabetologia. 2012 Jul;55(7):2016-25.

18. Ngamjariyawat A, Turpaev K, Welsh N, Kozlova EN. Coculture of insulin-producing RIN5AH cells with neural crest stem cells protects partially against cytokine-induced cell death. Pancreas. 2012 Apr;41(3):490-2. 
19. Olerud J, Kanaykina N, Vasylovska S, Vasilovska S, King D, Sandberg M, et al. Neural crest stem cells increase beta cell proliferation and improve islet function in co-transplanted murine pancreatic islets. Diabetologia. 2009 Dec;52(12):2594-601.

20. Kosykh A, Ngamjariyawat A, Vasylovska S, Konig N, Trolle C, Lau J, et al. Neural crest stem cells from hair follicles and boundary cap have different effects on pancreatic islets in vitro. Int J Neurosci. 2015;125(7):547-54.

21. Di Giorgio FP, Carrasco MA, Siao MC, Maniatis T, Eggan K. Noncell autonomous effect of glia on motor neurons in an embryonic stem cell-based ALS model. Nat Neurosci. 2007 May;10(5):60814.

22. Jungblut M, Tiveron MC, Barral S, Abrahamsen B, Knöbel S, Pennartz S, et al. Isolation and characterization of living primary astroglial cells using the new GLAST-specific monoclonal antibody ACSA-1. Glia. 2012 May;60(6):894-907.

23. Bryson JB, Machado CB, Crossley M, Stevenson D, Bros-Facer V, Burrone J, et al. Optical control of muscle function by transplantation of stem cell-derived motor neurons in mice. Science. 2014 Apr;344(6179):94-7.

24. Wichterle H, Lieberam I, Porter J a, Jessell TM. Directed differentiation of embryonic stem cells into motor neurons. Cell. 2002;110(3):385-97.

25. Vintersten K, Monetti C, Gertsenstein M, Zhang P, Laszlo L, Biechele S, et al. Mouse in red: red fluorescent protein expression in mouse ES cells, embryos, and adult animals. Genesis. 2004 Dec;40(4):241-6.

26. Aldskogius H, Berens C, Kanaykina N, Liakhovitskaia A, Medvinsky A, Sandelin M, et al. Regulation of boundary cap neural crest stem cell differentiation after transplantation. Stem Cells. 2009 Jul;27(7):1592-603.

27. Lepore AC. Intraspinal cell transplantation for targeting cervical ventral horn in amyotrophic lateral sclerosis and traumatic spinal cord injury. J Vis Exp. 2011 Sep 18;(55).

28. Arras M, Autenried P, Rettich A, Spaeni D, Rülicke T. Optimization of intraperitoneal injection anesthesia in mice: drugs, dosages, adverse effects, and anesthesia depth. Comp Med. 2001;51:443-56.

29. Grapensparr L, Vasylovska S, Li Z, Olerud J, Jansson L, Kozlova E, et al. Co-transplantation of human pancreatic islets with postmigratory neural crest stem cells increases $\beta$-cell proliferation and vascular and neural regrowth. J Clin Endocrinol Metab. 2015 Apr;100(4):E583-90.

30. Ngamjariyawat A, Turpaev K, Vasylovska S, Kozlova EN, Welsh N. Co-culture of neural crest stem cells (NCSC) and insulin producing beta-TC6 cells results in cadherin junctions and protection against cytokine-induced beta-cell death. PLoS One. 2013 Jan;8(4): e61828.

31. Ravits J. Focality, stochasticity and neuroanatomic propagation in ALS pathogenesis. Exp Neurol. 2014 Dec;262 Pt B:121-6.
32. Recasens A, Dehay B. Alpha-synuclein spreading in Parkinson's disease. Front Neuroanat. 2014;8:159.

33. Rotunno MS, Bosco DA. An emerging role for misfolded wild-type SOD1 in sporadic ALS pathogenesis. Front Cell Neurosci. 2013 Dec 16;7:253.

34. Basso M, Pozzi S, Tortarolo M, Fiordaliso F, Bisighini C, Pasetto L, et al. Mutant copper-zinc superoxide dismutase (SOD1) induces protein secretion pathway alterations and exosome release in astrocytes: implications for disease spreading and motor neuron pathology in amyotrophic lateral sclerosis. J Biol Chem. 2013 May 31;288(22):15699-711.

35. Lau J, Vasylovska S, Kozlova EN, Carlsson P-O. Surface coating of pancreatic islets with neural crest stem cells improves engraftment and function after intraportal transplantation. Cell Transplant. 2015;24(11):2263-72.

36. Hooten KG, Beers DR, Zhao W, Appel SH. Protective and toxic neuroinflammation in amyotrophic lateral sclerosis. Neurotherapeutics. 2015 Apr;12(2):364-75.

37. Tovar-Y-Romo LB, Ramírez-Jarquín UN, Lazo-Gómez R, Tapia R. Trophic factors as modulators of motor neuron physiology and survival: implications for ALS therapy. Front Cell Neurosci. 2014;8:61.

38. VanSaun MN, Matrisian LM. Matrix metalloproteinases and cellular motility in development and disease. Birth Defects Res C Embryo Today. 2006 Mar;78(1):69-79.

39. Tonti GA, Mannello F, Cacci E, Biagioni S. Neural stem cells at the crossroads: MMPs may tell the way. Int J Dev Biol. 2009;53(1):117.

40. Moore SA. The spinal ependymal layer in health and disease. Vet Pathol. 2016 Jul;53(4):746-53.

41. Meletis K, Barnabé-Heider F, Carlén M, Evergren E, Tomilin N, Shupliakov O, et al. Spinal cord injury reveals multilineage differentiation of ependymal cells. PLoS Biol. 2008 Jul 22;6(7):e182.

42. Ormerod BK, Palmer TD, Caldwell MA. Neurodegeneration and cell replacement. Philos Trans R Soc Lond B Biol Sci. 2008 Jan 12;363(1489): 153-70.

43. Butti E, Cusimano M, Bacigaluppi M, Martino G. Neurogenic and non-neurogenic functions of endogenous neural stem cells. Front Neurosci. 2014;8:92.

44. Garbuzova-Davis S, Hernandez-Ontiveros DG, Rodrigues MCO, Haller E, Frisina-Deyo A, Mirtyl S, et al. Impaired blood-brain/ spinal cord barrier in ALS patients. Brain Res. 2012 Aug 21;1469:114-28.

45. Garbuzova-Davis S, Sanberg PR. Blood-CNS barrier impairment in ALS patients versus an animal model. Front Cell Neurosci. 2014;8: 21.

46. Winkler EA, Sengillo JD, Sagare AP, Zhao Z, Ma Q, Zuniga E, et al. Blood-spinal cord barrier disruption contributes to early motor-neuron degeneration in ALS-model mice. Proc Natl Acad Sci USA. 2014 Mar 18;111(11):E1035-42. 